
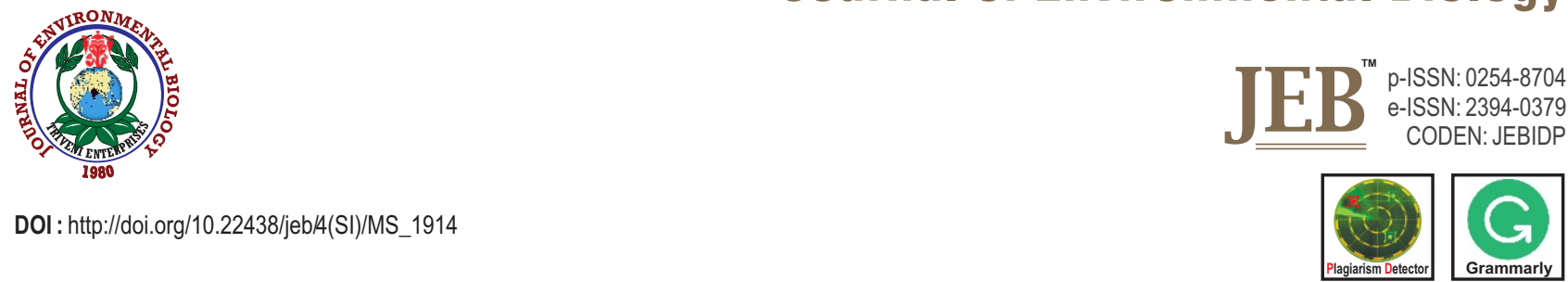

\title{
Biodiversity of ecologically important earthworms in subtropical forest ecosystems of East and West Imphal districts of Manipur
}

\author{
R.S. Thounaojam* and B.S. Thingbaijam \\ Department of Zoology, Manipur University, Imphal-795 003, India \\ *Corresponding Author Email : rjemeitei@gmail.com
}

\section{Abstract}

Aim: To investigate the community structure (composition) of ecologically important earthworm species and to assess the diversity, density and evenness in subtropical climatic condition of Manipur, Northeast India.

Methodology: Samples were collected from two subtropical forest ecosystems of valley districts of Manipur, North-east India under Indo-Burma Biodiversity hotspot. Tropical soil biology and fertility methodology was used in sample collection at monthly interval for a period of one year (January to December, 2018).

Results: Altogether eight earthworm species belonging to six genera under four families were observed and identified from the study sites. Five species (Metaphire birmanica, $M$. houlleti, M. anomala, Kanchuria sumerianus, Perionyx sp.), family Megascolecidae represented highest species composition and remaining families viz., Glossoscolecidae (Pontoscolex corethrurus), Moniligastridae (Drawida sp.), Octochaetidae (Eutyphoeus sp.) were represented by one species each. Diversity was high at Site-I compare to Site-II. Pontoscolex corethrurus and Drawida sp. were found throughout all the seasons during the sampled period.

Interpretation: It is concluded that forests with high canopy cover with less human interference favour the presence of higher diversity of earthworm than forests with less canopy cover in subtropical forest ecosystems of Manipur.

Keywords: Biodiversity, Earthworm, Hotspot, Subtropical

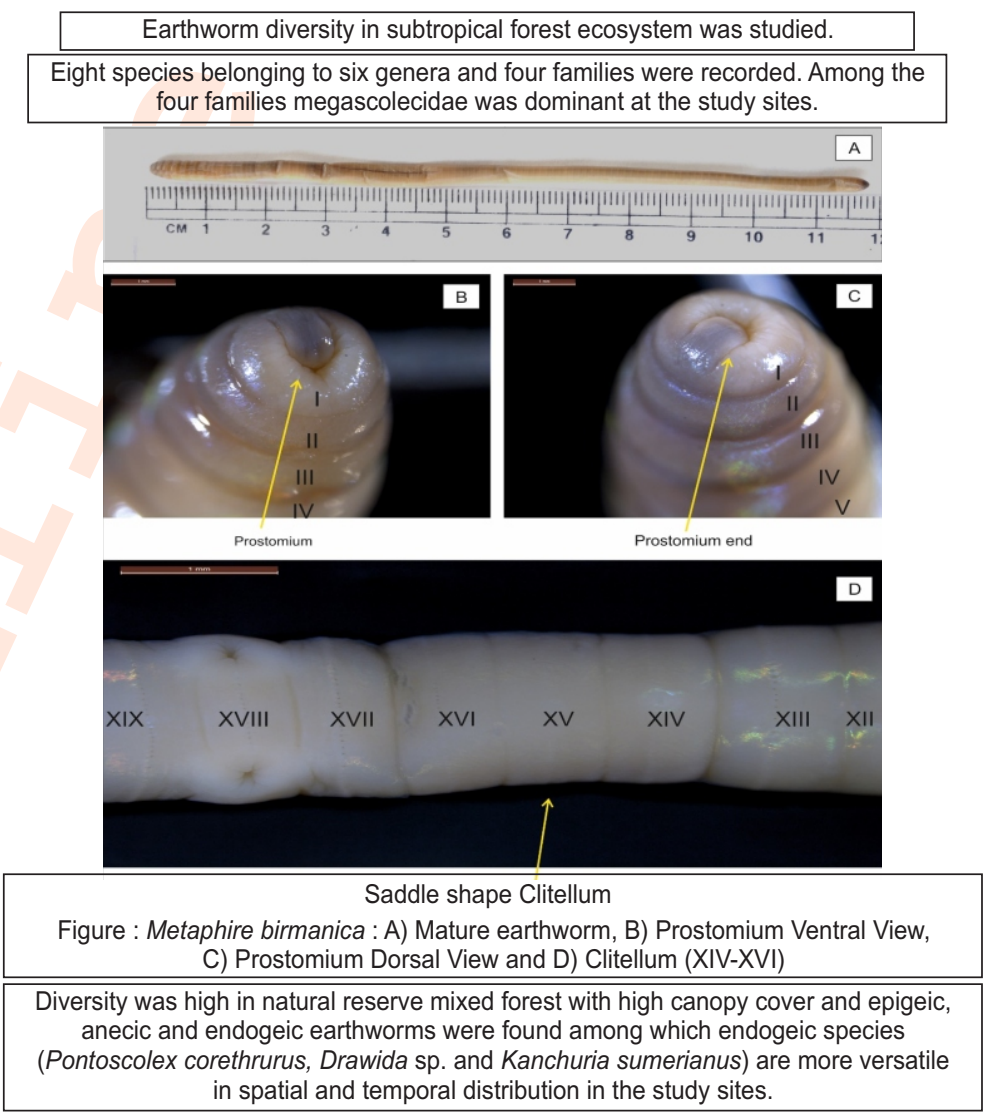

How to cite : Thounaojam, R.S. and B.S. Thingbaijam: Biodiversity of ecologically important earthworms in subtropical forest ecosystems of East and West Imphal districts of Manipur. J. Environ. Biol., 41, 951-956 (2020). 


\section{Introduction}

Soil takes various roles including fertility role, filter and reservoir, structural role, climate regulation role, biodiversity conservation role and resource role in providing ecosystem services (Dominati et al., 2010). Soil host a number of organisms among which earthworm is also one of them. Among terrestrial habitat, soil ecosystem can be taken as one of the most species rich habitat (Wolters, 2001) at 23\% of the total biodiversity so far described and represented as fauna of soil ecosystem (Lavelle, 2006). Millennium ecosystem assessment, (2005) defines ecosystem services as benefits provided by ecosystem to humankind as well as to other species. Ecosystem services provided by soil are made possible by the activities of soil biota. Soil invertebrate play a vital role in providing soil ecosystem services in many ways, viz., water supply, nutrient cycling, primary production, soil formation, climate regulation, as indicator of soil function and quality (Lavelle, 2006). Earthworms have significant positive effects on growth and biomass of plants (Edwards, 2004). Earthworms belong to the Phylum Annelida, Class Oligochaeta and Order Opisthophora. They are one of the most important groups of soil biota that help in the formation of soil and also maintain soil structure and fertility, thereby assisting in ecosystem health. This particular group is also used in waste management, bioremediation and vermiculture. On the basis of body width, soil organisms have been classified into microflora (100 $\mu \mathrm{m}$, e.g., bacteria, fungi), microfauna (5-120 $\mu \mathrm{m}$, e.g. protozoa, nematodes), mesofauna (80 $\mu \mathrm{m}-2 \mathrm{~mm}$, e.g. collembolan, acari) and macrofauna $(500 \mu \mathrm{m}-50 \mathrm{~mm}$, e.g. earthworms, termites) (Borrios, 2007).

Earthworms represent the most abundant animal biomass in majority of terrestrial ecosystems (Blouin, 2013) and contribute to more than $80 \%$ of soil invertebrate biomass (Chaudhuri et al., 2012). Earthworms can be divided into three primary ecological categories namely epigeic, anecic and endogeic earthworms, (Fragoso and Lavelle, 1995), each of which describes a different grouping of earthworm species based on their ecology and may contribute to ecosystem processes and services differently. Epigeic earthworm species live in and feed on leaf litter on the soil surface and do not make burrows, their body size is small $(5-15 \mathrm{~cm})$ and bright red in colour (Dewi and Sedge, 2015), but they are not stripy. They play vital role in decomposition of organic matter at the soil surface. Anecic earthworms make permanent vertical burrows and live in it. They feed on leaves on the soil surface and drag it into the burrows (Fragoso et al., 1997), their body size is large $(15-20 \mathrm{~cm})$ and coloured on the dorsal side (Keith and Robinson, 2012). They can reach up to 1-2m depth (Dewi and Senge, 2015) and increase aeration and water infiltration through their burrows. Species, like Lumbricus terrestris, make middens (piles of cast material) around the entrance to their burrows. They also play a vital role in litter comminution and nutrient cycling by combining leaf litter into the soil profile. Endogeic species live in and feed on the soil. They make network of horizontal burrows. Size of the body is approximately 5-10 cm, usually unpigmented (often pale colour). Most species of endogeic earthworms are found at the top layers of soil, though some can burrow deep in the soil. The physicochemical and biological characteristics of soil ecosystem is considered good when all the three primary ecological categories of earthworms are inhabiting (Dewi and Senge, 2015).

Quantification of the belowground biodiversity in the region is less although it is under biodiversity hotspot. It is likely that species become extinct before they are described as a result of changing habitat condition. A constituent of highly bio-diverse Indo-Burma biodiversity hotspot, Manipur state in North-east India has remained more or less unexplored for earthworm diversity, except for the work conducted by Haokip and Singh (2017). In the "Indian oligochaete," Stephenson, (1921) had recorded only five species of earthworm from the state.

Keeping in view the importance of earthworms and their functions, it is essential to investigate the earthworm species of Manipur. Further, it is necessary to study possible impacts on ecosystems which is likely to be caused by changes in species composition (among exotic, native, epigeic, anecic and endogeic species) and reduce or loss of earthworm diversity in subtropical forests. Necessary steps are needed to maintain stable ecosystem for healthy ecosystem services which are vital for existence of life.

In view of the above, the research work was conducted to study the earthworm diversity in subtropical forest of Manipur which plays a vital role in maintaining the stability of ecosystems and conservation as the biodiversity of earthworms is a key determinant of ecosystem stability. The present study aims at finding the earthworm species occurrence at an old growth mixed forest and young mixed forest. It was predicted that old growth mixed forest will host higher number of species diversity than the young forest. Investigations of species diversity in the forests of this region are very much important as the state is represented by a total forest coverage area of $78.01 \%$ and Conservation of natural ecosystems is required since endemism of earthworm species is very high in the region (about $71 \%$ of the genera and $89 \%$ of the species are endemic, Julka, 2014).

\section{Materials and Methods}

Site description: The study was conducted in two subtropical forest ecosystems in east and west Imphal districts of Manipur, Northeast India under Indo-Burma biodiversity hotspot. Manipur is hilly state situated in the North-Eastern part of India covering $22,327 \mathrm{~km}^{2}$ area. It shares international border with Myanmar and lies between $23^{\circ} 50^{\prime}$ and $25^{\circ} 42^{\prime} \mathrm{N}$ latitude and $92^{\circ} 59^{\prime}$ and $94^{\circ} 59^{\prime} \mathrm{E}$ longitude. The study sites I and II lies at $24^{\circ} 52^{\prime} 43.85^{\prime \prime} \mathrm{N}$, $93^{\circ} 54^{\prime} 26.87^{\prime \prime} \mathrm{E}$ and $24^{\circ} 53^{\prime} 41.16^{\prime \prime} \mathrm{N}, 93^{\circ} 58^{\prime} 20.59^{\prime \prime} \mathrm{E}$ respectively. 
Site-l is a reserve mixed forest located in Imphal west district and Site-II is community protected mixed forest in Imphal east district in the valley area of Manipur. The area is characterized by a typical subtropical monsoon climate. The region receives an average annual rainfall of $1325.7 \mathrm{~mm}$.

Sampling and Identification of earthworms: Samples were collected from two different subtropical mixed forest ecosystem of Manipur, following Anderson and Ingram (1993) at monthly interval for a period of one year (January to December, 2018). In the present study, six plots of $1 \mathrm{~m}^{2}$ were demarcated at each study site. Further, in each plot, four $25 \times 25 \times 30 \mathrm{~cm}^{3}$ soil monoliths were randomly sampled at study sites for sampling of earthworms. The samples were collected by digging an area of $25 \times 25 \times 30 \mathrm{~cm}^{3}$. Earthworms were hand sorted, straightened using 20-30\% preservative and preserved in $4 \%$ formalin for further identification. The samples were identified under a Magnus zoom stereo tri-nocular microscope (MODEL MSZ-TR) and Leica stereo-zoom microscope SApo.

Soil temperature was measured on monthly basis using digital soil thermometer and $\mathrm{pH}$ was measured in 1:2 ratio soil water solution using digital $\mathrm{pH}$ meter. Soil moisture content was determined by gravimetric method and expressed as percentage of the sampled weight. Soil temperature of the study sites ranged from $15-25^{\circ} \mathrm{C}, \mathrm{pH}$ value 5 to 6 while the soil moisture content ranged from $19-36 \%$ at site-I and $18-39 \%$ at site-II, respectively.

Data analyses: Species richness, Diversity and Evenness indices were calculated by using Margalef's Index (Margalef,1968), Shannon's Wiener Diversity Index (Shannon and Weaver, 1949), Simpson's Index (Simpson, 1949), Pielou's Evenness Index (Pielou, 1975). Sorensen's Coefficient of Community Index and Percent Similarity (PS) index were used to measure the similarity between two study sites based on the species composition and Density of earthworms (ind. $\mathrm{m}^{-2}$ ) was also calculated.

\section{Results and Discussion}

In the present study, a total of eight species were recorded from two subtropical forest ecosystems of valley district of Manipur (Table 1). The recorded species belonged to six genera and four families of the Class Oligochaeta. Majority of the species belonged to Megascolecidae with five species viz. Metaphire birmanica (Rosa, 1888), M. houlleti (Perrier, 1872), M. anomala (Michaelsen, 1907), Kanchuria sumerianus (Julka, 1988), and Perionyx sp. and the remaining families Glossoscolecidae, Octochaetidae and Moniligastridae were represented by Pontoscolex corethrurus (Muller, 1856), Eutyphoeus sp. and Drawida sp. respectively. Three species of the family Megascolecidae ( $M$. birmanica, $M$. houletti and $M$. anomala) and Perionyx sp. of the family (Megascolecidae) were found at Site-I, whereas, Eutyphoeus sp. (Octochaetidae) was found only at Site-II. Species $P$. corethrurus, K. sumerianus and Drawida sp. were present at both the sites. Out of the recorded earthworm species, species of the family Megascolecidae ( $M$. birmanica, $M$. houlleti and $M$. anomala) and one species of the family Octochaetidae ( $P$. corethrurus) were exotic. Among the recorded families, species belonging to the family Megascolecidae was dominant over other families viz., Glossoscolecidae, Moniligastridae, Octochaetidae at the study sites. The dominant occurrence of the species belong to the family Megascolecidae may be due to their diverse adaptability in the Indian subcontinent (Julka et al., 2009; Zodinpuii et al., 2019).

Natural reserved mixed forest (Site-I) had higher species richness and species diversity index value and lower evenness index value than Site-II (Table 2). All the ecological categories of earthworm viz., epigeic, anecic and endogeic were recorded from Site-I on the other hand only two categories (epigeic and endogeic) were found at Site-II. This may be because of the higher canopy cover and higher litter fall in Site-I than Site-II (Ruan et al., 2005). Endogeic species such as $P$. corethrurus and Drawida sp. (Table 1) were more versatile in both spatial and temporal distribution as they were occurring during all the seasons upto $30 \mathrm{~cm}$ deep soil, while others mostly occurred at 0 $10 \mathrm{~cm}$ deep soil. This may be because of the ability of the species to thrive well in different environmental situations such as draught, heat and cold winter (Bhattacharjee and Chaudhuri, 2002).

In the present study, the similarity index analysis between the two study sites showed similarity in species composition (Sorensen's co-efficient of community: 0.66 and Percent similarity: 59.9) despite differences in the tree canopy cover (table 2). The strong similarity observed in species composition between the two sites may be due to similar microclimate and mixed forest type (Haokip and Singh, 2012).

High species diversity (Shannon's diversity index: 1.29; Simpsons index of dominance: 0.42 ) observed at Site-I may be due to more canopy cover, high litter fall, which may provide more suitable habitat for existence of earthworm community and leading to the presence of anecic earthworms ( $M$. birmanica, $M$. houlleti, M. anomala) which are absent in Site-Il having less canopy cover and litter fall (Gonzalez and Zou, 1999). Forests with high litter fall and accumulation on ground favour higher soil macro-faunal diversity due to territorial space, food and shelter availability and also protection from predators (Ruan et al., 2005). Less species diversity and richness observed in Site-II may be due to less canopy cover, litter fall and little flexibility to biotic interference like collection of dry wood materials, edible plant materials which may disturb their habitat such as forest floor and upper soil layers (Eisenhauer and Schadler, 2011). Site-I has lesser evenness index value (0.66) than Site-II (0.72) (Table 2) which may be due to the presence of more number of species 
Table 1 : Distribution of earthworm species in two study sites of subtropical forest ecosystem in Manipur

\begin{tabular}{lllll}
\hline Family/Species & Site I & Site II & Vertical distribution & Ecological category \\
\hline Megascolecidae Metaphire birmanica & + & - & $0-10 \mathrm{~cm}$ & Anecic \\
M. houlleti & + & - & $0-10 \mathrm{~cm}$ & Anecic \\
M. anomala & + & - & $0-10 \mathrm{~cm}$ & Anecic \\
Kanchuria sumerianus & + & + & $0-20 \mathrm{~cm}$ & Endogeic \\
Perionyx sp. & + & + & $0-10 \mathrm{~cm}$ & Epigeic \\
Glossoscolecidae Pontoscolex corethrurus & ++ & ++ & $0-30 \mathrm{~cm}$ & Endogeic \\
Moniligastridae Drawida sp. & ++ & ++ & $0-30 \mathrm{~cm}$ & Endogeic \\
Octochaetidae Eutyphoeus sp. & - & + & $0-10 \mathrm{~cm}$ & Endogeic \\
\hline
\end{tabular}

+= present; - = absent; ++ = high density

Table 2 : Earthworm diversity indices in sites I and II

\begin{tabular}{lll}
\hline Indices & Site-I & Site-II \\
\hline Margalef's index & 0.81 & 0.52 \\
Shannon's diversity index & 1.29 & 1.17 \\
Simpsons index of dominance & 0.42 & 0.37 \\
Pielou's eveness index & 0.66 & 0.72 \\
\hline
\end{tabular}

Similarity indices: 1 . Sorensen's co-efficient of community: 0.66 ; 2 . Percent similarity: 59.9

Table 3 : Seasonal variation in the population density $\left(\mathrm{m}^{-2}\right)$ of earthworm species at Sites I and II

\begin{tabular}{|c|c|c|c|c|}
\hline Earthworms & Sites & Summer & Rainy & Winter \\
\hline \multirow[t]{2}{*}{ Metaphire birmanica } & I & $A$ & $14.5 \pm 3.4$ & $A$ \\
\hline & $\|$ & $A$ & A & $A$ \\
\hline \multirow[t]{2}{*}{ M. houlleti } & I & $A$ & $23.25 \pm 2.5$ & $A$ \\
\hline & $\|$ & $A$ & A & $A$ \\
\hline \multirow[t]{2}{*}{ M. anomala } & I & $A$ & $13.25 \pm 1.5$ & $A$ \\
\hline & $\|$ & $A$ & A & A \\
\hline \multirow[t]{2}{*}{ Kanchuria sumerianus } & l & $A$ & $23.00 \pm 1.8$ & $6.00 \pm 1.4$ \\
\hline & $\|$ & $A$ & $19.2 \pm 2.59$ & $3.00 \pm$ \\
\hline \multirow[t]{2}{*}{ Perionyx sp. } & I & $A$ & $27.00 \pm 2.94$ & A \\
\hline & $\|$ & A & $26.00 \pm 2,94$ & A \\
\hline \multirow[t]{2}{*}{ Pontoscolex corethrurus } & I & $100 \pm 10.58$ & $102.4 \pm 6.06$ & $54.00 \pm 13.56$ \\
\hline & $\|$ & $41.33 \pm 5.50$ & $97.6 \pm 11.7$ & $66.00 \pm 12.90$ \\
\hline \multirow[t]{2}{*}{ Drawidasp. } & l & $18.4 \pm 2.17$ & $20.33 \pm 1.52$ & $12.00 \pm 1.63$ \\
\hline & $\|$ & $56.00 \pm 7.00$ & $135.2 \pm 11.17$ & $49.00 \pm 15.81$ \\
\hline \multirow[t]{2}{*}{ Eutyphoeussp. } & i & A & A & A \\
\hline & $\|$ & A & $26.00 \pm 4.06$ & $7.00 \pm 1.41$ \\
\hline
\end{tabular}

$A=a b s e n t$

which were very less and even absent during summer and winter. It may also be due to the presence of exotic species which affect the population of native species (Winsome et al., 2006).

In the present study, most of the earthworm species and populations were found in the uppermost surface layer $(0-10 \mathrm{~cm})$ and very less in remaining soil layers $(10-20 \mathrm{~cm}$ and $20-30 \mathrm{~cm})$ irrespective of the forest type and soil at both the study sites. Earthworm distribution in soil layers are influenced by both abiotic and biotic factors (Lavelle and Martin, 1992). High species population in the uppermost layer may be due to presence of favourable temperature, moisture content and availability of leaf litter, which are necessary for the survival of earthworms (Baker,
1998; Whalen et al., 1998; Aroujo and Hernandez, 1999; Tian ., 2000; Peterson., 2001; Kale and Karmegam, 2010). The Presence of less number of earthworms in deeper layer may be due to compact texture of the soil resulting from various factors such as reduced volume of pore in soil, less oxygen and temporary water logging in soils (Bostrom, 1986) which do not favour the activities of earthworm efficiently. The present finding of spatial distribution of species corroborates the findings of Irannejad and Rahmani (2009) and Zodinpuii et al. (2019) where more diversity and density was observed in the uppermost soil layer $(0-10 \mathrm{~cm})$.

Seasonal variation in the population density of earthworm was observed in the present study. Earthworm population density 
was highest during rainy season as compared to summer and winter seasons for all recorded species at both the study sites. High population density observed during rainy season may be due to suitable moisture content which is essential for earthworm survival (Edwards and Bohlen,1996). Favourable soil moisture content along with other factors like temperature and availability of litter provide suitable conditions for earthworm breeding and thus increasing their population density during rainy season (Najar and Khan, 2011; Lalthanzara and Ramanujam, 2014).Thus, it can be concluded that forests with high canopy cover with less human interference favour high diversity of earthworm than forests with less canopy cover in subtropical forests ecosystems of Manipur.

\section{Acknowledgments}

I would like to thank Jawaharlal Nehru Memorial Fund, Teen Murti House, New Delhi for providing financial support in the form of scholarship and also Dr. Rahul Paliwal for identifying and training of earthworm species.

\section{References}

Anderson, J.M. and J.S.I. Ingram: Tropical Soil Biology and Fertility: A Handbook of Method. $2^{\text {nd }} E d n$., C.A.B. International, Wallingford (1993).

Araujo, Y. and D.L. Hernandez: Earthworm populations in a savannaagroforestry system of Venezuelan Amazonia. Biol. Fertil. Soils, 29, 413-418 (1999).

Baker, G.H.: The ecology, management and benefits of earthworms in agricultural soils, with particular reference to southern Australia In: Earthworm Ecology (Ed.: C.A. Edwards), St Lucie Press, Boca Raton, pp. 229-257 (1998).

Barrios, E.: Soil biota, ecosystem services and land productivity. Ecol. Econ., 64, 269-285 (2007).

Bhattacharjee, G. and P.S. Chaudhuri: Cocoon production, morphology, hatching pattern and fecundity in seven tropical earthworm species - a laboratory based investigation. J. Biosci., 27, 283-294 (2002).

Blouin, M., M.E. Hodson, E.A. Delgado, G. Baker, L. Brussaard, K.R. Butt, J. Dai, L. Dendooven, G. Peres, J.E. Tondoh, D. Cluzeau and J.J. Brun: A review of earthworm impact on soil function and ecosystem services. Eur. J. Soil Biol., 64, 161-182 (2013).

Bostrom, U.: The effect of soil compaction on earthworms (Lumbricidae) in a heavy clay soil. Swed. J. Agri. Res., 16, 137-141 (1986).

Chaudhuri, P.S., A. Dey, G. Bhattacharjee and S. Nath: Earthworm diversity in Tripura - a present status. Sci. Cult., 78, 317-321 (2012).

Dewi, W.S. and M. Senge: Earthworm diversity and ecosystem services under threat. Rev. Agricul. Sci., 3, 25-35 (2015).

Dominati, E., M. Patterson and A. Mackay: A framework for classifying and quantifying the natural capital and ecosystem services of soils. Ecol. Econ., 69, 1858-1868 (2010).

Edwards, C.A. and P.J. Bohlen: Biology and Ecology of Earthworms. $3^{\text {rd }}$ Edn., Chapman and Hall, London (1996).

Edwards, C.A.: Earthworm Ecology. $2^{\text {nd }}$ Edn., CRC Press, Florida (2004).

Eisenhauer, N. and M. Schadler: Inconsistent impacts of decomposer diversity on the stability of aboveground and belowground ecosystem functions. Oecologia, 165, 403-415 (2011).

Fragoso, C. and P. Lavelle: Are earthworms important in the decomposition of tropical litter? In: Soil Organisms and Litter Decomposition in Tropics (Ed.: M.V. Reddy). Oxford and IBH Publishing Co. New Delhi (1995).

Fragoso, C., G.G. Brown, J.C. Patron, E. Blanchart, P. Lavelle, B. Pashanasi, B. Senapati and T. Kumar: Agricultural intensification, soil biodiversity and agroecosystem function in the tropics: The role of earthworms. Appl. Soil Ecol., 6, 17-35 (1997).

Gonzalez, G. and X. Zou: Plant and litter influences on earthworm abundance and community structure in a tropical wet forest. Biotropica, 31, 486-493 (1999).

Haokip, S.L. and T.B. Singh: Diversity and distribution of earthworms in a natural reserved and disturbed sub-tropical forest ecosystem of Imphal-West, Manipur, India. Int. Multidiscip. Res. J., 2, 28-34 (2012).

Haokip, S.L. and T.B. Singh: Comparative studies on the earthworm community structure in the natural mixed and oak plantation subtropical forests ecosystem of Imphal, Manipur, India. Intl. J. Eco. Env. Sc., 43, 319-329 (2017).

Irannejad, E. and R. Rahmani: Evaluation of earthworm abundance and vertical distribution pattern in some forest types of Shast-Kolateh. J. For. Wood Prod., 62, 145-157 (2009).

Julka, J.M.: Fauna of India and the Adjacent countries: Megadrile Oligochaeta (Earthworms). Zoological Survey India, Kolkata, (1988).

Julka, J.M., R. Paliwal and Kathireswari: Biodiversity of Indian earthworms an overview. In: Proceedings of Indo-US Workshop on Vermitechnology in Human Welfare (Eds.: C.A. Edwards, R. Jayaraaj and I.A. Jayraaj). Rohini Achagam, Coimbatore, India, pp. 36-56 (2009).

Julka, J.M.: Diversity and distribution of exotic earthworms (Annelida, Oligochaeta) in India a review. In: Biology and Ecology of Tropical Earthworms (Eds.: P. Chaudhuri and S.M. Singh). Discovery Publishing House, New Delhi, pp. 73-83 (2014).

Kale, R.D. and N. Karmegam: The role of earthworms in tropics with emphasis on Indian Ecosystems. Appl. Environ. Soil Sci., 2010, 1-16 (2010).

Keith, A.M. and D.A. Robinson: Earthworms as natural capital: Ecosystem service providers in agricultural soils. Economol. J., II, 91-99 (2012).

Lalthanzara, H. and S.N. Ramanujam: Vertical distribution of earthworms in agro forestry system of Mizoram, India. In: Biology and Ecology of Tropical Earthworms (Eds.: P.S. Chaudhuri and S.M. Singh) DPH, India, pp. 126-140 (2014).

Lavelle, P. and A. Martin: Small-scale and large-scale effects, of endogeic earthworms on soil organic matter dynamics in soils of the humid tropics. Soil Biol. Biochem., 24, 1491-1498 (1992).

Lavelle, P., T. Decaens, M. Aubert, S. Barot, M. Blouin, F. Bureau, P. Margerie, P. Mora and J. P. Rossi: Soil invertebrates and ecosystem services. Eur. J. Soil Biol., 42, 3-15 (2006).

Margalef, R.: Perspectives in ecological theory. University Chicago Press, Chicago, Illinois (1968).

Michaelsen, W.: Neue Oligichaeten von Vorder-Indien, Ceylon, Birma und den Andaman-Inseln. Mitteilungenaus dem Naturhistorischen Museum, 24, 143-188(1907).

Millenium EcosystemAssessment: Ecoystem and Human Welbeing : Synthesis. World Resources Institute, Washington, D.C. (2005).

Muller: Lumbricuscorethrurus, Bürstenschwaz. Archivfür 
Naturgeschichte, 23, 113-116 (1856).

Najar, I.A. and A.B. Khan: Earthworm communities of Kashmir Valley, India. Trop. Ecol., 52, 151-162 (2011).

Perrier, E.: Recherches pour server a l'histoire des Lombricinsterrestres. Nouvelles Archives du Museum d'histoire Naturelle, 8, 195-198 (1872).

Peterson, A.C., P.F. Hendrix, C. Haydu, R.C. Graham and S.A. Quideau: Single-tree influence on earthworms and soil macroarthropods in the southern California chaparral. Pedobiologia, 45, 509-522 (2001).

Pielou, E.C.: Ecological diversity. John Wiley, New York (1975).

Rosa, D.: Viaggio di Leonardo Fea in Birmanica e regionivicine, VPreichetidi. Annali del Museo Civico di Storia Naturale, Giacomo Doria, 6, 155-167 (1888).

Ruan, H.H., Y.Q. Li, and X.M. Zou: Soil communities and plant litter decomposition as influenced by forest debris: Variation across tropical riparian and upland sites. Pedobiologia, 49, 529-538 (2005).

Shannon, C.E. and W. Weaver: The mathematical theory of communication. University Illinois Press, Urbana, IL (1949).

Simpson, E.M.: Measurement of diversity. Nature, 163, 688 (1949).
Stephenson, J.: Oligochaeta from Manipur, The Laccadive Islands, Mysore and other parts of India. Indian Oligochaetes, XXII, pp. 745-767 (1921).

Tian, G., J.A. Olimah, G.O. Adeoye and B.T. Kang: Regeneration of earthworm populations in a degraded soil by natural and planted fallows under humid tropical conditions. Soil Sci. Soc. Am. J., 64, 222-228 (2000).

Whalen, J.K., R.W. Parmelee and C.A. Edwards: Population dynamics of earthworm communities in corn agroecosystems receiving organic or inorganic fertilizer amendments. Biol. Fertil. Soils, 27, 400-407 (1998).

Winsome, T., L. Epstein, P.F. Hendrix and W.R. Horwath: Habitat quality and interspecific competition between native and exotic earthworm species in a California grassland. Appl. Soil Ecol., 32, 38-53 (2006).

Wolters, V.: Biodiversity of soil animals and its function. Eur. J. Soil Biol., 37, 221-227 (2001).

Zodinpuii, B., H. Lalthanzara and Lalnuntluanga: Earthworm diversity, density and distribution under shifting (Jhum) cultivation in a tropical hilly terrain of Mizoram, North-east India. J. Environ. Biol., 40, 995-1002 (2019). 